\title{
Inquiry-Based Learning: An Attempt to Enhance Students' Speaking Performance
}

\author{
Riwayati Yanu Fatkhriyah ${ }^{1}$ \\ ${ }^{1}$ SMA Negeri 1 Kepanjen
}

\begin{tabular}{|c|c|}
\hline INFO ARTIKEL & ABSTRAK \\
\hline Riwayat Artikel: & $\begin{array}{l}\text { Abstract: This study aimed to investigate how the Inquiry-Based Learning strategy can } \\
\text { improve the speaking skills of the students. This collaborative classroom action research }\end{array}$ \\
\hline Diterima: 17-01-2019 & was conducted in two cycles. The result of this study revealed the average speaking met \\
\hline Disetujui: $23-07-2019$ & the first criterion of success. Considering to the result of the questionnaire toward the \\
\hline
\end{tabular}

inquiry-based learning; speaking skills; collaborative classroom action research

\begin{abstract}
Abstrak: Penelitian ini bertujuan untuk meneliti bagaimana strategi pengajaran menggunakan Inquiry-Based Learning dapat meningkatkan kemampuan berbicara Bahasa Inggris bagi siswa. Penelitian Tindakan Kelas secara kolaboratif ini dilakukan dalam dua siklus. Hasil dari penelitian ini menunjukkan bahwa rata-rata nilai berbicara siswa dalam kriteria sukses yang pertama. Sementara itu, hasil dari kuesioner untuk siswa menunjukkan bahwa sebagian besar siswa memiliki tanggapan yang baik terhadap pelaksanaan kegiatan belajar mengajar dengan menggunakan Inquiry-Based Learning ini.
\end{abstract}

\author{
Alamat Korespondensi: \\ Riwayati Yanu Fatkhriyah \\ SMA Negeri 1 Kepanjen \\ Jalan Ahmad Yani No.48, Ardirejo, Kec. Kepanjen, Malang \\ E-mail: yanufatkhriyah@gmail.com
}

As a spoken communication, speaking has two functions. Brown and Yule in explain that the functions of speaking are as interactional and transactional function. For interactional function, speaking has a role to control and create social interaction. Meanwhile, for transactional function, speaking is to focus on the information change. Related to the function of speaking, (Harmer, 2007)) suggests that the speaker differ its function. For transactional function, the speakers are hoped to convey the information clearly, while for the interpersonal one, it is expected that the good relation between the speakers remains good. In addition, (Brown \& Lee, 2015) mention some kinds of speaking, namely monologue, dialogue, planned, spontaneous, interpersonal and transactional speaking. Dealing with those types of speaking, the speakers have to be able to vary their intention of speaking. For interactive purpose, the speakers can carry out it when they have conversation with a shop assistant in a certain shop to buy something. For non-interactive purpose, the speaker may complete it to leave message for their colleague in office after answering a call. Meanwhile, for planned speaking, the speakers, as a teacher for instance, could perform it to give instruction in a class (Harmer, 2007).

One of the important aspects of speaking that the speakers have to notice is speaking fluency. Lennon in (Rossiter, 2009) divides speaking fluency into two, namely broad and narrow sense. For broad sense, fluency is to deal with expression for verbal ability that it shows the highest point on a scale that clarifies spoken performance of foreign language. For narrow sense, fluency in English as foreign language refers to component of oral proficiency, such as in procedures for grading oral examinations involving correctness, relevance, appropriateness, pronunciation, lexical range, and so on. This narrow sense is also employed by the teachers to know whether the students have "fluent but grammatically inaccurate", or "fluent but lacks vocabulary", or "speak correctly but not very fluent"

There have been several studies concerning to the improvement of speaking performance. One of them is a study by (Ismail, 2014) that mainly discussed about speaking skills improvement by using group discussion strategy. In the same area of the topic, (Walusi, 2016) conducted a study about Numbered Head Together strategy. In addition, to enhance the students' speaking skills, (Al-Tamimi \& Attamimi, 2014) accomplished a study to examine the efficacy of cooperative learning strategy regarding the students' speaking skills. The writer used quasi experimental study in which the students were to work in small group to help each other. The result of the study showed that there was positive change in terms of the students' speaking skills and attitude. 
Another study from Baniabdelrohman (2013) examined whether shared oral diaries strategy affected Saudi students' English speaking proficiency. In this study, he conducted pre and post test where the students had to describe chart, figure, pictures and demonstration or role card. The result showed that after using oral diaries, the students' participation and motivation in English class increased, and their confidence in showing their speaking skills also enhanced.

In addition to the study concerning to the speaking skills improvement, (Malmir \& Shoorcheh, 2012) conducted a study to improve the students' speaking skill by involving critical thinking strategy in their teaching English. The result showed that there was significant influence on Iranian EFL students' speaking ability because the result indicated that the students who got instruction on critical thinking strategy did better in oral interview post test. Moreover, (Abdolrezapour, 2017) investigated whether emotional intelligence through computer mediated activities could affect students' L2 oral skill. Surprisingly, the result showed that emotional intelligence had positive correlation with the development of students' level of oral fluency. (Rachmawaty \& Hermagustiana, 2015) also conducted a study to investigate whether retelling technique could improve students' speaking fluency. After assigning some students to join remedial class and to read certain story then retell it, there was significant improvement of the students' speaking fluency. A study investigating the development of speaking fluency was conducted by (Hunter, 2011). With the belief that small talk strategy was good to help students communicate without teacher's intervention, this study discovered that there was positive correlation between small talk strategy application with students' speaking accuracy, complexity and fluency development.

Accordingly, in SMAN 1 Kepanjen, it was needed to improve the students' language skills, especially speaking. The students of X MIPA 6 were considered to have more attention to enhance their speaking skills because the students did not have much vocabulary to express their idea through spoken performance. In addition, the teacher stated that it was demanding to make them speak up because they had difficulties in grammar and using appropriate tense. Moreover, since they did not understand the structure of certain text, most of them told the past experience not in sequence way or unsystematically. In addition, one of the problems when the students had to exhibit their speaking performance fluently was that they were nervous or less confident to do so that they paused during their presentation.

In line with the problems above, the result of the questionnaire in preliminary study specified that the students were afraid to speak English in front of the class. They also stated that being not confident, lacking of vocabulary and difficulty to pronounce English properly were their obstacles to have fluent verbal performance. In addition, grammar was their most complex problem to deliver certain spoken text. The students' problems in demonstrating their speaking skills shown in figure 1.

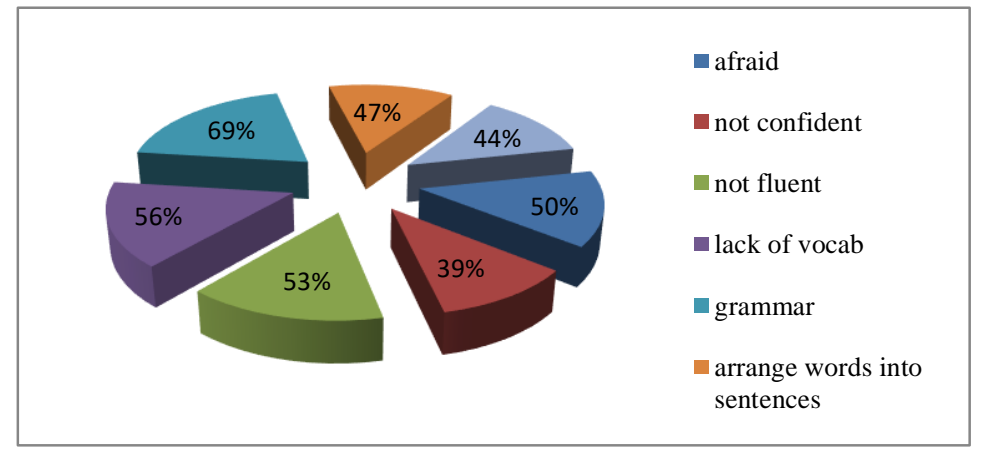

\section{Figure 1. The Students' Problems in Demonstrating Their Speaking Skills}

Considering the facts about the language teaching strategies above, the researcher of this study attempts to compare them with Inquiry-Based Learning. As proposed by The Ministry of Education and Culture of Indonesia (Masitoh, 2016) IBL is defined as a process where the students formulate questions, investigate them widely, build new understandings, meanings and knowledge, and are involved in their learning. The knowledge is new to the students and may be used to answer a question, to develop a solution or to support a position or point of view. The knowledge is usually presented to others and may result in some sort of action (Learning, 2004).

From that point of view, the researcher believes that Inquiry-Based Learning is a teaching and learning activity that involve all students' competencies maximally to find and investigate something systematically, critically, logically with proper analysis so that they can formulate their own finding (Direktorat Pembinaan Sekolah Menegah Atas Direktorat Pendidikan Dasar dan Menengah Kementrian Pendidikan dan Kebudayaan, 2017). In this type of learning, the students are trained to collect additional information by themselves, make hypothesis and test it. In accordance with this, the teacher plays important role to direct, advice, and give information about the data needed. IBL offers various stages in its teaching and learning process. Based on (Kampa \& Vilina, 2016), Inquiry-Based Learning follows a three-step process that the teacher can incorporate into many 
curriculums. The students ask themselves three questions about any new subject being introduced: what they already know about the subject, what they want to know about the subject, and what they have learned about the subject.

In addition, (Beach \& Myers, 2001) state that the six inquiry strategies may fall into (1) immersing, (2) identifying, (3) contextualizing, (4) representing, (5) critiquing, and (5) transforming. In immersing stage, the students enter into the activities of a social world, experience the social world as a participant, or observe a certain social world. In language class activity, it can be visualized when the students get involve with the other students in a group discussion. The students become the participants of the discussion to observe the topic. While in identifying stage, the students define concerns, issues, and dilemmas that arise in a social world or from conflict across multiple social worlds. For speaking activity, this stage allows the students have more discussion to solve the problem arising in the topic being discussed. Then in contextualizing stage, the students are supposed to explain how the activities, symbols, and texts used in one or more social worlds produce the components of a social worldidentities, roles, relationships, expectations, norms, beliefs, and values. Considering to those stages, we can conclude that the students are given opportunity to express their ideas their ideas through spoken language performance. After passing this stage, (Beach \& Myers, 2001) add that the students then have to use symbolic tools to create a text that represents a lived social world or responds to a represented social world in representing stage. Critiquing, a stage to analysing how particular literacy practices within a social world promote certain meanings, will fall after the representing stage, then followed with transforming stage to revise one's meanings for the components of a social world, changing one's actions and words within a social world to construct more desirable identities, relationships, and values.

Dealing with English Language Teaching (ELT) context, there have been several studies conducted to investigate how IBL has good impact to the students' skill improvement. (Oktariani, 2015) carried out a study with the purpose to describe whether IBL strategy could develop students' reading comprehension and to analyze what factors could enhance students' reading comprehension. Her study was classroom action research. After two cycles, the number of the student who reached or passed the passing grade had met the criteria of success. A study about the application of IBL was also conducted by (Blessinger \& Carfora, 2014). Their study reported that through IBL the students were more able to both use their international phonetics alphabet and hear and make correction to their own mistakes. Furthermore, their study also found that students made few mistakes in terms of pronouncing sounds.

To add the idea of using IBL, (Ermawati \& Pammu, 2017) tried to find how IBL was applied in classroom and whether IBL improved students' reading comprehension. With the IBL's five stages to apply, namely (1) engagement, where students engaged with the topic being discussed, (2) exploration, where students explored the process by reading strategies, (3) explanation, where students were to explain the result of the reading strategy, (4) elaboration, where students answered the questions related to the text, and (5) evaluation, where both teacher and students evaluated the whole process, the result showed that IBL implementation in ELT was good to improve students' reading comprehension of EFL.

Furthermore, (Sholeh, 2008) carried out classroom action research to improve the students' writing ability by using Inquiry-Based Learning. Although there was no satisfactory result in cycle 1 - because the teacher's explanation and instruction were in English that not all students understood it - the finding in cycle 2 showed that IBL could improve the students' writing ability. From the data analyzing, the writing achievement from pre-test was 4.6 in a 0 to 10 scale. In test 1 , the average score of the students' writing ability increased to 5.9, then in cycle 2, it increased to 7.1. In addition, (Sholeh, 2008) concluded that with IBL, the students were more active, gained more mean score, and had chance for greater independence. Another study about the implementation of IBL was conducted by (Thayibah, 2013) reporting that this teaching strategy increased the students' score on opinion essay writing. With the stages of asking, investigating, creating, discussing and reflecting, IBL attracted the students to involve to those five stages and the result was that they participated actively during the class discussion.

In line with the idea above, (Puspitasari, 2014) explored that those five stages in IBL could engage the students to express their ideas in discussion activity, guide them to construct some questions related to someone's information, guide them to investigate or observe the objects and allow them to do writing procedures. The result showed that the students' writing performance improved, and they met the criteria of success. In terms of the students' participation, the field note described that most students participated in all stages and paid attention to the teacher's instructions. From the previous studies, it can be noticed that IBL has attracted the researchers' attention to improve the students' English performance, such as reading comprehension and writing, including opinion essay writing. IBL was also implemented to enhance the students' ability to use International Phonetic Alphabet. However, the possibility of improving the students' speaking skills through IBL has not been investigated. So, this study aims to fill this gap by investigating how IBL can improve the students' speaking skills.

To summarize, there are many studies concerning on how to improve the students' English skills performance through various teaching strategies. In this case, IBL is reported to be much less implemented in ELT especially to investigate the students' speaking skills improvement. Meanwhile, relating to the 2013 Curriculum, IBL is one of the important teaching models that is good to meet the basic competence, including promoting speaking skills. So, this study is different from the previous studies that have been mentioned above. The differences are on the skills, material, and strategy. The speaking skills will be the focus of this study with Recount text as the material, and Inquiry-Based Learning as the strategy. 


\section{METHOD}

This study used Collaborative Classroom Action Research (CAR) design. This design was chosen because there were feasible problems faced by both students and teachers in English instructions that needed to be solved, especially in speaking class.

The CAR design in this study followed (Kemmis dan McTaggart, 1988), with their spiral of self-reflection in terms of a spiral of self-reflective cycles of planning a change, acting and observing the process and consequences of the change, reflecting on these processes and consequences, and then re-planning, acting and observing, reflecting, and so on. For this study, those steps were preceded by a preliminary study. In this study, the researcher was assisted by a collaborator who was the classroom teacher and whose duty as the partner of the researcher from beginning to the end of the study, including in designing the lesson plan, determining the criteria of success, observing the teaching and learning process in the classroom and doing the reflection.

This study was conducted in SMAN 1 Kepanjen Kabupaten Malang, which is located at Jl. Ahmad Yani 48 Kepanjen, Kabupaten Malang, East Java. The researcher chose this school because the school's vision and mission has met the Management Standards of National Education Standard. Based on the Permendiknas Nomor 19, Tahun 2007 (Regulation of The Ministry of Education and Culture of Indonesia Number 19, Year 2007), an education institution has to formulate, determine and develop its own vision and mission. In line with this idea, one of the missions of SMAN 1 Kepanjen, specifically mission 2, is to create interactive, inspiring, enjoyable, challenging and motivating teaching and learning atmosphere. So, the researcher believed that Inquiry-Based Learning was good to answer this challenge based on the following reasons. The subjects of the study were the students of Tenth Science Program 6. The considerations to determine these students as the subjects were because the researcher found that this class still had problems with speaking, and the students' speaking performance was categorized low.

To decide whether the cycle was successful or not, the researcher set up the criteria of success. The criteria of success in this study were focused on the students' speaking performance and involvement during the teaching and learning process. For the students' speaking performance, which was evaluated by using scoring rubric for speaking performance, it was considered successful when $100 \%$ of the students got score greater than or equal to 70 which is the minimum passing grade (KKM) for Compulsory English for tenth graders. For the students' involvement during the teaching and learning process, it was considered successful when most of the students engaged themselves in the activity. To know whether the students were active or not, the researcher uses observation check list and field notes during the implementation of the IBL strategy. Then, to know the students' attitude toward the strategy, the researcher got the data from the questionnaires that had already been completed by the students. When more than $70 \%$ students had positive comments in each item, it was considered successful.

So, this study used four kinds of instruments namely speaking test, observation, field notes, and questionnaires. The instrument of data collection for a speaking test was speaking scoring rubric; for observation was observation checklist; for field notes were the collaborator's documents; and for questionnaire was list of questions about the students' responds toward the implementation of the strategy.

\section{FINDING}

\section{The Findings of the Study of Cycle 1}

Cycle 1 was conducted in six meetings with time allocation of 2 x 45 minutes for each meeting. The first meeting was used to introduce the Historical recount text and guide the procedure of Inquiry-Based Learning strategy. The second meeting was employed to introduce Mind Map, followed by the third meeting that was to train the students to retell a historical story through information gap. The fourth meeting was used to have simulation to present a historical recount text. In addition, the fifth and sixth meetings were used to evaluate the students' speaking skills through the students' presentation to retell a historical recount text.

\section{The Student' Speaking Skills}

The data of the students' speaking skills were gained from the students' spoken performance of retelling a Historical Recount text that was evaluated by using scoring rubric that was adapted from (H. D. Brown \& Abeywickrama, 2004; O'malley \& Pierce, 1996), with the aspects being scored of fluency, organization, content, grammar, vocabulary and pronunciation.

Based on the tabulation of the students' speaking score there was increase in terms of the number of the students who spoke fluently. Being compared with the result from the test in preliminary study, that there were no students who spoke fluently and no doubt, the result of the speaking test in cycle 1 showed that there were 4 students (11\%) who spoke fluently without any doubt. For the students who spoke fluently but sometimes with doubt, there was also increase on the number of the students, from 28 students to 31 students (85\%). Unfortunately, there was 1 student (3\%) who still spoke doubtfully.

About the text organization that the students presented in the speaking test, it can be seen that there was increase on the number of the students, from 6 students (17\%) to 16 students (44\%) who organized the text very carefully. However, the students who are able to carefully organize the text declined from 21 students $(58 \%)$ to 20 students $(56 \%)$. 
For the content of the Historical Recount text, there were 8 students (22\%) who had accurate and comprehensive content of the text they presented. It increased from 4 students $(11 \%)$. In addition, there was increase on the number of the students who had aaccurate and reasonably complete content of the text from 23 students $(64 \%)$ to 28 students $(78 \%)$.

For grammar aspect, the students showed their improvement on it. In the test in preliminary study, there were no students who used complex sentence in their presentation. Meanwhile, in the speaking test in cycle 1, there were 3 students (8\%) who could use complex sentence. Although there were 12 students $(33 \%)$ who used simple sentences in their presentation, the implementation of the teaching strategy showed a good result that there were 21 students (58\%) who used complex sentences despite with some mistakes.

Furthermore, the result of the speaking test in this cycle showed that 10 students (28\%) had good mastery of vocabulary. The result of the speaking test in preliminary study showed that there were 10 students $(28 \%)$ who mastered sufficient vocabulary of the text being presented. So, there was $62 \%$ increase as there were 26 students $(72 \%)$ who had sufficient vocabulary.

For pronunciation, the result of the speaking test in this cycle showed an increase in terms of pronouncing words by using correct intonation and pronunciation, that it was from 5 students (14\%) to 17 students ((47\%). Meanwhile, there was no increase dealing with the students who had correct intonation and pronunciation with few mistakes, it was 19 students (53\%).

From the explanation above, it can be concluded that the main problem the students had during the implementation of the teaching strategy was how to organize the text carefully based on the structure of Historical Recount text. Meanwhile, the proficiency that the students were able to exhibit was in having fluent speaking despite with doubt. Below is the tabulation of the students' speaking score in cycle 1 shown in figure 2.

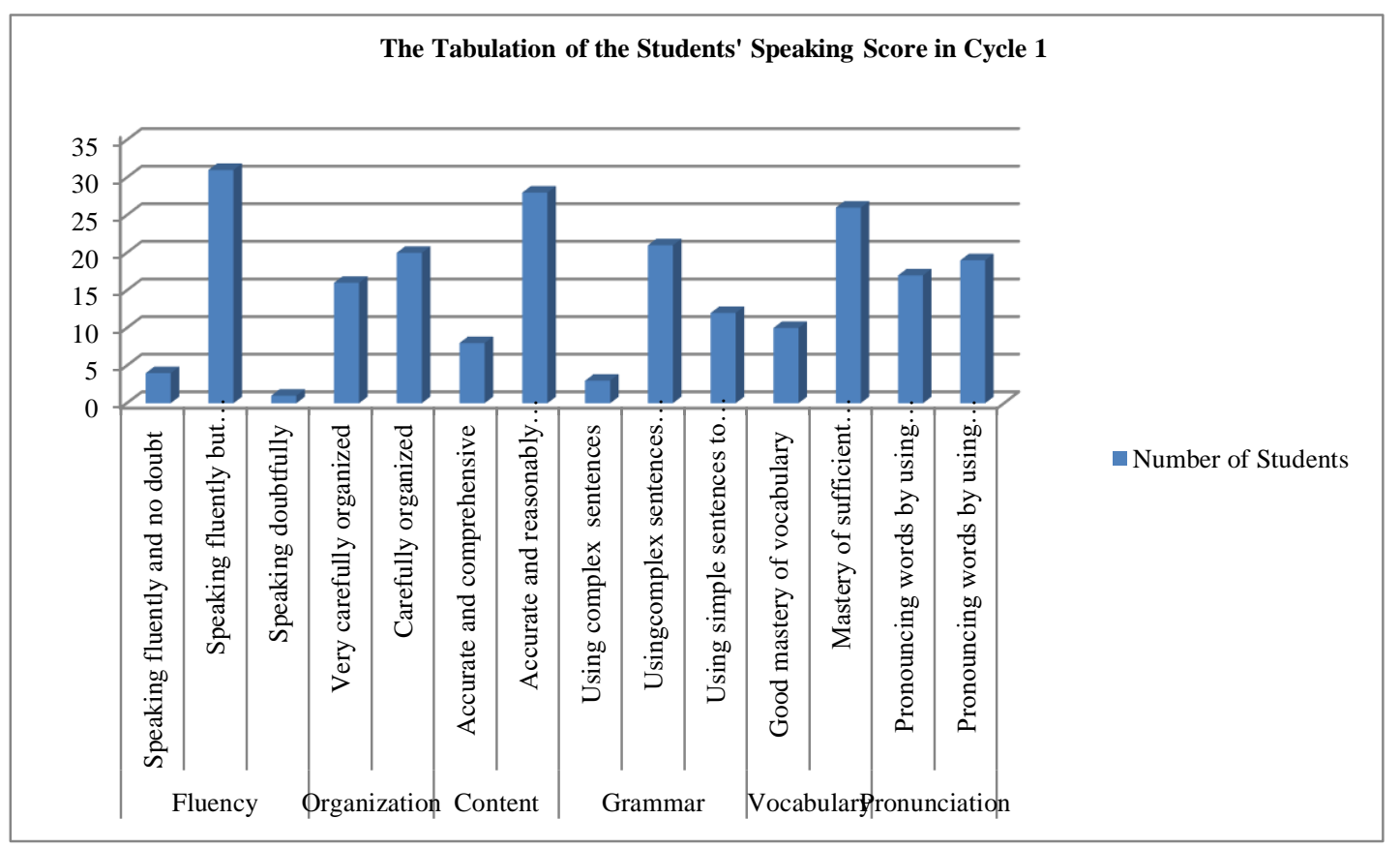

Figure 2. The Tabulation of the Students' Speaking Score in Cycle 1

Finally, there were 6 students who had not met the passing grade score. Meanwhile, 30 students had met it. Basically, the average score of the students' speaking performances has reached 72.25, but there are 6 students who have not get 70 , while the criterion of success requires $100 \%$ of the students get equal or greater than 70 . So, it can be concluded that the first criterion of success was not achieved yet.

\section{The Students' Involvement}

The data of the students' involvement during the teaching and learning process were taken from the observation checklist, filed note and questionnaire for students after the teaching and learning process was implemented. It was found that in the first meeting, most of the students showed their eagerness to have question and answer during the discussion and presentation, actively communicated with their friends to find information related to generic structure and language features of the text they discussed.

The observation of the second meeting revealed that most of the students paid attention to the teacher's instructions and feedback, friends' presentation, and observed the learning materials seriously although only half of the class who were brave enough to have questions and present the result of discussion. 
In the third and fourth meeting, there was increase in the number of the students that all of them paid attention to the teacher's instructions and feedback. Meanwhile, most of them had been eager to observe the learning material, make questions and answers, communicate with their friends both in group or other groups, exhibit their speaking performance to express the result of discussion, and pay attention to their friends' presentation.

Finally, in individual presentation time, both in the fifth and sixth meeting, most of the students had paid attention to their friends' presentation. They also tried to understand the story by generating questions.

Adding to the information about the students' involvement during the teaching and learning process, the result of the field note revealed that the first meeting in cycle 1 showed that after reading the text, having discussion, and getting feedback from the teacher, the students understood the aspects of Historical Recount text. Furthermore, the teacher used simple language to give instruction and feedback to the students. Since the students were still confused how to determine the aspects of certain text, such as the social function, generic structure and language features, they had to be accustomed to read more or prepare themselves before having materials in the classroom. Besides, two or three students showed their being uninterested in joining the classroom activity. So, they should be given understanding on the importance of listening to someone's explanation and involving to the activity. For the teacher, she was supposed to be able to manage the time regarding to the limited time and the materials to cover, including giving feedback to the students' problem to comprehend the language features of the Historical recount text.

From the result of the field note in the second meeting, the students enthusiastically made their own mind map because they could use color pencil to write and create it. But the teacher needed more time to give feedback on the mind map because it was related to the key words the students chose to be inputted in it. The students also tried to speak English although they were not fluent and sometimes chose inappropriate diction, and even mixed with Indonesian language (Bahasa Indonesia). Considering to this matter, the students needed to practice more on how to have conversation, discussion and questions. So, the teacher needed to have strategy to help them make questions when the other students had explanation or presentation.

In the third meeting, the field note exposed the students were happy to watch video although they worked hard to understand the story in it. Because the time was limited, some students could not complete the mind map they had to make. So, it would be better that the teacher played the video more than twice to make it more understandable.

From the fourth meeting, the students had been accustomed to create mind map based on the generic structure of Historical Recount text and they successfully told the story although they were nervous. In retelling the story, the students broke their presentation due to some words they forgot to state. So, the students need to practice to retell past story by using past tense as one of the language features.

From the fifth meeting, it was revealed that the students still had the problems in terms of fluency, language features of Historical Recount text, pronunciation, and vocabulary. So, based on those problems, the students needed to prepare and practice more and more. Finally, from the sixth meeting, the teacher was hoped to have more teaching strategies to overcome the problems occurring in the previous meeting. To add more information concerning to the students' involvement during the teaching and learning process, the chart below shows the result of the questionnaire to the students.

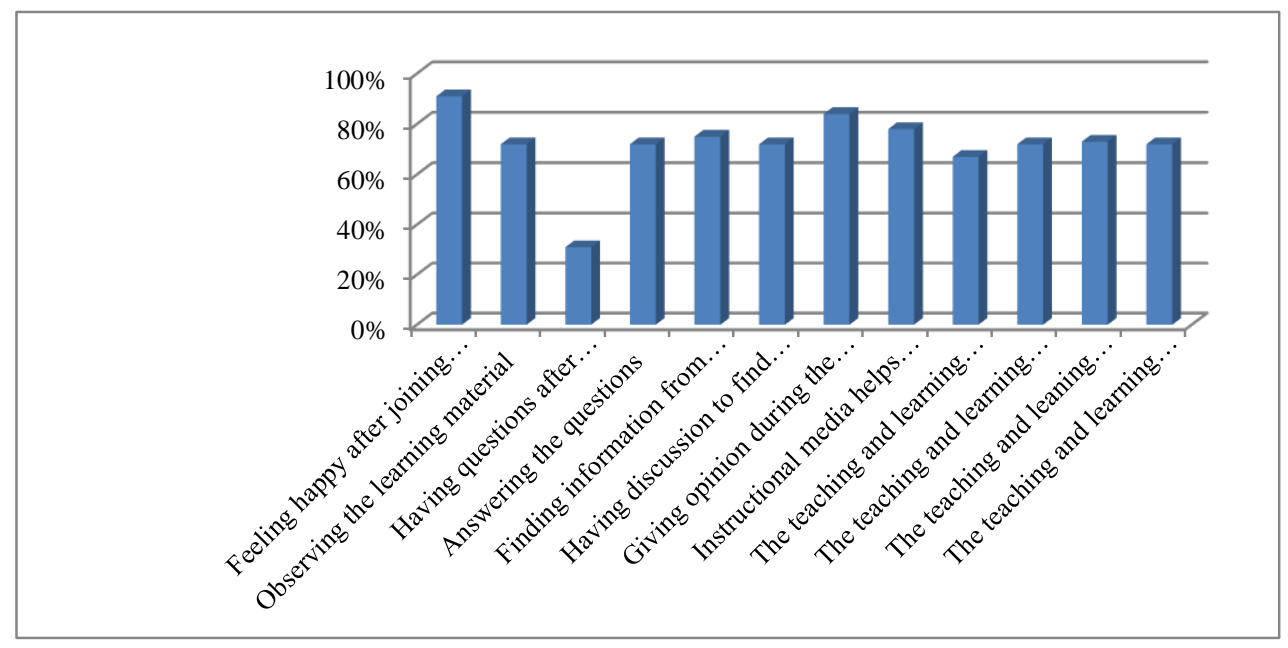

Figure 3. The Percentage of the Students' Respond toward the Teaching and Learning Activity in Cycle 1 
Basically, $91 \%$ of the students were happy after joining the teaching and learning activity. In terms of implementing Inquiry-Based Learning, there were $72 \%$ of the students who observed the learning material or read the text thoroughly. However, in the process of having questions, there were only $31 \%$ of the students who demonstrated positive attitude, with $72 \%$ of the students who tried to respond the questions. In the stage of finding information from the other resources, there were $75 \%$ of the students who responded it positively. Moreover, in the discussion process, there were $84 \%$ students who actively involved in the discussion.

Regarding to the implementation of the teaching strategy, $78 \%$ students responded or stated that this teaching strategy helped them speak using English, and $67 \%$ students claimed that this strategy was enjoyable. Even $72 \%$ of them said that this strategy increased their confidence, and $73 \%$ of the students claimed it enhanced their learning motivation. In conclusion, $72 \%$ of the students declared that teaching and learning activity with this strategy was effective.

Considering to the result of the questionnaire for the students after the teaching and learning activity were conducted, $71.58 \%$ of the students had good responds towards the implementation of IBL in teaching Speaking with 11 students (31\%) who formulated questions during the questioning stage. To sum up, it has met the criteria of success of this study.

\section{Summary of the Findings of Cycle 1}

Reflecting to the result of data analysis in cycle 1, the researcher came to the conclusion that the first criterion of success that $100 \%$ of the students get score greater than or equal to 70 which is the minimum passing grade score (KKM) for Compulsory English for tenth graders has not been achieved yet because there were six students who got score under 70 . For the second criterion of success, that more than $70 \%$ of the students have positive comments in each item in the questionnaire, it can be concluded that it has met this criterion of success because it was $71.58 \%$ of the students who had good responds relating to the implementation of IBL in teaching Speaking. Therefore, the researcher conducted the cycle 2 by revising some aspects and actions of the teaching strategy.

\section{The Findings of the Study of Cycle 2}

Cycle 2 was conducted in three meetings with time allocation of $2 \times 45$ minutes for each meeting. The first meeting was managed to drill the students to understand the generic structure of Historical Recount text. With the modification of the worksheet, the students were to listen to spoken jumbled paragraphs of certain historical story, then arrange them chronologically.

\section{The Students' Speaking Skills}

Based on the tabulation of the students' speaking score in cycle 2, there were 9 students (25\%) who spoke fluently and without any doubt. In terms of organization, that it was the main problem of the students' speaking performance in cycle 1 , there was an increase that 24 students $(67 \%)$ delivered the historical story with very carefully organized text. In addition, there were 18 students $(50 \%)$ who had accurate and comprehensive content. Being compared with the result from cycle 1, it increased $28 \%$.

For the grammar aspect, it was an increase both in using complex sentence and using complex sentence with some mistakes. There were 9 students $(25 \%)$ who used complex sentence, and 27 students $(75 \%)$ had used complex sentence with some mistakes. Adding the information towards the students' speaking performance in cycle 2, there was $8 \%$ increase from the cycle 1 in terms of the number of the students who mastered the vocabulary. For the pronunciation aspect, there was an increase related to the number of the students that 23 students (64\%) had pronounced words by using correct intonation and pronunciation. Regarding to the students' speaking skills, the chart below shows the result of the students' speaking performance in figure 4.

Furthermore, the average speaking score was 76.69. All students had reached the minimum passing grade score (KKM), 70. So, it has met the first criterion of success that $100 \%$ of the students get equal or more than 70 .

\section{The Students' Involvement}

The data of the students' involvement during the implementation of the strategy were taken from the observation checklist and field note. From the observation of the students' involvement during the implementation of the strategy, the first meeting revealed that all of the students had paid attention to the teacher's instruction and feedback, and friends' presentation. They also immersed themselves seriously in observing the materials, showed eagerness to have questions and answers, communicated actively with other students to find information. However, not all students presented their findings of discussion fluently and independently.

Furthermore, the second and third meetings were for the students' speaking performance in retelling the historical recount text. From the observation, it can be noticed that the result was fairly the same. Most of the students paid attention to the teacher's instruction and communicated actively with the other students to find information toward the presentation they had perceived. All of the students formulated questions and answers, presented the story fluently and independently, and paid attention to the teacher's feedback and other friends' presentation. 
Adding to the information about the students' involvement during the teaching and learning process, the result of the field note in the first meeting confirmed that the students had paid attention to the teacher's instruction and feedback. They were also eager to propose questions by writing them on a piece of paper. For the students' understanding about the generic structure of the text, the teacher was supposed to provide more time to give feedback on the students' difficulty in sequencing the events of the story.

In the second meeting, the field note showed that the students had told the story chronologically, while the other students listened to it seriously. The thing to consider from this meeting was that the students should be more confident to retell the story so that they were not busy to prepare their won presentation while the other students had their speaking performance. It also suggested that the teacher had to find another way to attract the students' attention to their friends' presentation, and provide time for the students to have question and answer after having presentation. Finally, the third meeting revealed that the students had paid attention to their friends' presentation so that the teacher should provide more time to give feedback to it. Concerning to the point about the students' involvement in the teaching and learning process, the chart below is the finding of the questionnaire to students.

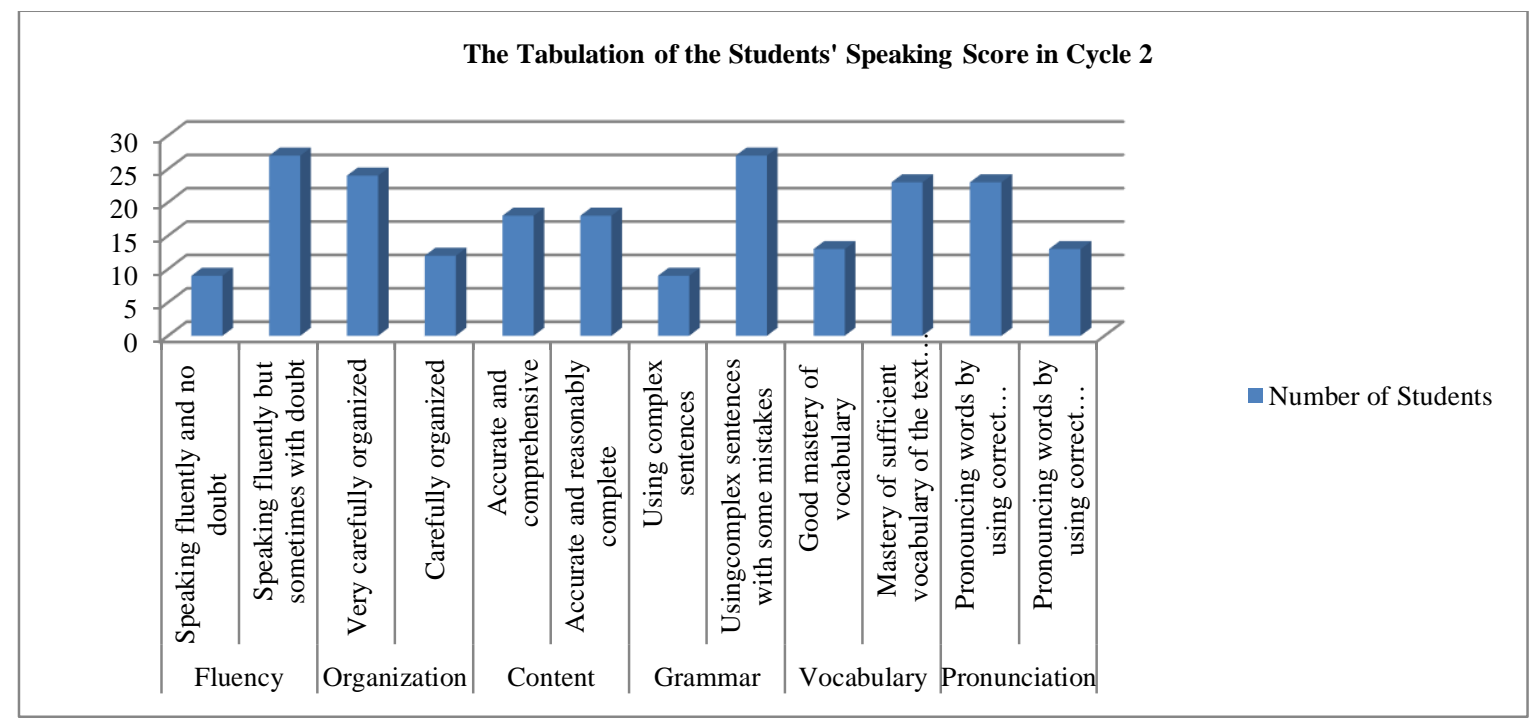

Figure 4. The Tabulation of the Students' Speaking Score in Cycle 2

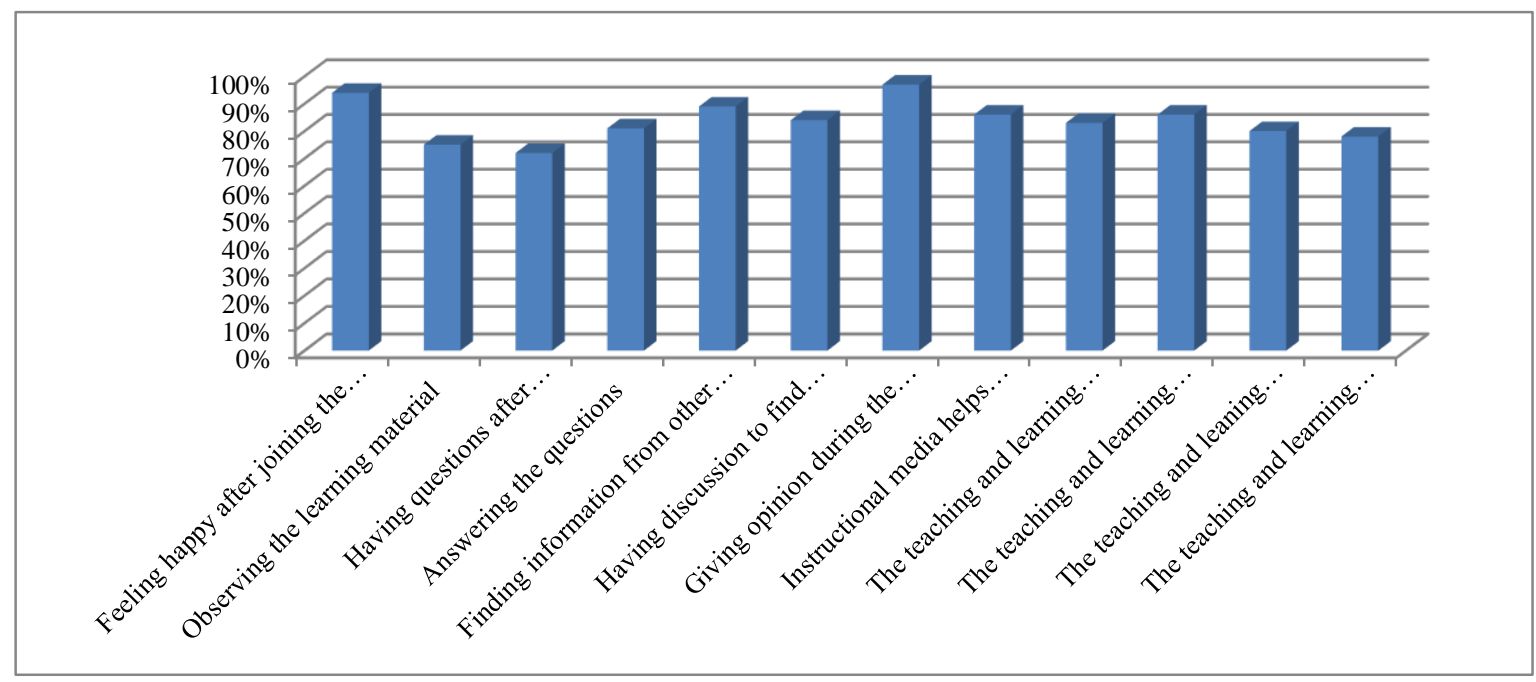

Figure 5. The Percentage of the Students' Respond toward the Teaching and Learning Activity in Cycle 2 
Mostly, 94\% of the students felt happy after joining the teaching and learning activity using Inquiry-Based Learning. For the implementation of the strategy, especially in the observation stage, $75 \%$ of the students showed positive attitude by observing the learning materials. $72 \%$ of the students also proposed questions after observing the materials, with $81 \%$ of them answered the questions. Moreover, $89 \%$ of the students demonstrated positive attitude in terms of finding information from the other resources. To more understand the materials, $83 \%$ of the students said that they discussed with their friends and $97 \%$ of the students gave their opinion during the discussion. Regarding to the use of the instructional media, $86 \%$ of the students claimed that it helped them speak English.

Furthermore, for the entire teaching and learning activity, $83 \%$ of the students declared that it was enjoyable. It also encouraged the students' self-confidence and motivated them to study English. Finally, 78\% of the students stated that this teaching and learning process improved their speaking skills. Considering to the result of the questionnaire toward the students' attitude after joining the implementation of the teaching strategy, $84 \%$ of the students had good respond to the implementation of Inquiry-Based Learning. So, it can be concluded that it has met the second criterion of success of this study.

\section{Summary of the Findings of Cycle 2}

Based on the result of data analysis in cycle 2, the researcher concluded that the first criterion of success that $100 \%$ of the students get score greater than or equal to 70 as the minimum passing grade for Compulsory English for the tenth graders has been achieved since the average of the total score was 76.69 or $100 \%$ of the students had reached the minimum passing grade. Moreover, the second criterion of success that more than $70 \%$ students have positive comments in each item has been attained since $84 \%$ of the students showed their positive attitude through giving positive respond to each item.

\section{DISCUSSION}

There are some important aspects to concern from the implementation of the action both in cycle 1 and 2 . The first aspect is grouping the students into small groups and asking them to work with their groups. With the small groups, the interacting activity is able to be controlled that the students would easily find information and keep it as well (River in Lin \& Chien, 2010). Working with small groups also increases the student autonomy (Ur, 2012) that they decide their own choice in terms of determining the language to use, rather than the teacher choose it for them. Although working with group is not suitable for certain students with certain learning styles, it is still considered fun to cooperate with the other students with the solidarity and warmth developed.

The second aspect considered important during the implementation of the action is discussion. In terms of preparing the students to have speaking skills, the teacher was in line with (Bala Kumaravadivelu, 2003) that teachers have to dedicate themselves to the development of situated participations. In this point of teaching, the teacher of this study gave the students opportunity to have discussion with their groups to either arrange jumbled paragraphs or train themselves to retell certain historical story in front of the class.

Discussion is one of the most important parts to be done by the students in their small groups. However, there were few students who were reluctant to speak or give their opinion. It was because the students were not confident or thought that their English language proficiency was not enough for them to blend in the discussion. (Harmer, 2001), to answer this difficulty, the teacher sets "Buzz Group" in which the students have chance to have brief discussion with their groups before one of them is asked to present the result of the discussion in front of the class. For instance, when the students had to present the mind map they had created, the first thing they did was discussing to complete and develop the mind map with the key words. They also discussed and trained themselves to tell what was in the mind map and finally one of them was pointed to present it in front of the class.

The third aspect that is important to consider from the implementation of the study is that this study concerns to the improvement of the students' speaking skills. However, the teacher did not merely focus on speaking skill in every teaching and learning process. Through the learning activities in Inquiry-Based Learning, the teacher emphasized the use of language interactively where integrated activities occurred. It made the students get through the discussion with their groups, do brainstorm to understand the text, and use various learning resources to get information (Bala Kumaravadivelu, 2003). With this kind of activity, the students performed integrated language skills, namely listening, speaking, reading and writing.

Since the teacher wanted to maximize the learning opportunities for the students with different characters, it was customary that there were integrated tasks (Harmer, 2007). In line with this idea, (Laslett \& Smith, 2002) proposed an activity called "Smoothness" in which the students move from one activity to another activity. In terms of integrated tasks, the teacher asked the students to watch video, listen to the dialog in the video, write down the key words, and then retell the story in the video to their friends. While listening to their friends' telling the story, the task was that they had to write important words and develop their own mind map for the help to have chronological story to tell in front of the class. 
The last aspect to ponder from the implementation of the action is that improving the students' speaking skills cannot be separated from the students' involvement in the speaking activity. (Balasubramanian Kumaravadivelu, 2006) noted that the teacher has to facilitate the negotiated interaction. With this kind of interaction, there was communication between the students in the class that the students had freedom and flexibility to initiate and handle the conversation, not merely reacted and responded the talk.

When the result of data analysis in cycle 1 had not met the criteria of success, the researcher revised the action or teaching and learning activities. Based on (Bala Kumaravadivelu, 2003), one of the teachers' roles is as transformative intellectual in which their teaching is devoted to the teaching and learning quality improvement. For the cycle 2, the teacher modified the lesson plan by employing different teaching strategies. To cope with this, the teacher created learning opportunities. According to (Balasubramanian Kumaravadivelu, 2006), teachers are the creator of learning opportunities and have to maximize them by modifying the lesson plans. Since the students' weakness in this study was unwilling to ask questions during the teaching and learning process, the teacher modified the learning activities by applying the strategy where the students were asked to write down their questions on a piece of paper then stick on the board then answer the questions.

According to (Kampa \& Vilina, 2016), the basic concept of Inquiry-Based Learning is that it is started with open-ended questions that lead many possible answers. Those questions can trigger the students to think deeply and critically towards things or learning materials. (Lee, William \& Owens, 2014) also notes that questioning can strengthen the students' linguistic and communicative competence. When the students propose questions, the teacher is able to notice the students' comprehension of the paragraphs or texts they had read. In this study, before the students made the questions, the teacher gave example of how to make questions, dealing with the linguistic structure or the substance of the questions.

\section{CONCLUSION}

Based on the findings and discussion of the study, it can be concluded that Inquiry-Based Learning (IBL) strategy can improve the students' speaking skills. It could be seen from the students' speaking score from the test in preliminary study, cycle 1 , and cycle 2. It could also be seen from the students' attitude after joining the teaching and learning process. Previously, the students were afraid to speak English in front of the class due to some reasons, such as lack of vocabulary, pronunciation, and grammar. IBL finally made them perform their spoken English skills.

Through IBL, there was improvement of the students' speaking skills. It could be seen from the students' speaking score. In cycle 1, the students' main problem was how to organize the story based on the generic structure of historical recount text. After being taught by using IBL, the number of the students who had that problem decreased from 56\% to 33\%. The improvement could also be seen from the students' involvement during the teaching and learning activity since they showed positive attitude toward the strategy. They also had good respond toward this strategy as they are happy after joining the class.

Based on the finding of the study, some suggestions are proposed to improve the quality of the teaching and learning process in the future. For English teachers, Inquiry-Based Learning (IBL) is one of the alternative strategies with the stages that are appropriate with the scientific approach proposed by The Ministry of Education and Culture of Indonesia for 2013 Curriculum. IBL is applicable to teach the basic competence of producing spoken text. To implement this strategy, the teachers may consider the following suggestions.

For future researchers, they can conduct similar classroom action research using this strategy at different grade or level of education or different basic competence proposed by the ministry of education and culture of the republic of Indonesia for 2013 curriculum. Furthermore, the future researchers need to investigate whether IBL can improve the other language skills with the specific basic competence for the other level of education. Finally, other studies are needed to investigate whether IBL can be applied to improve the students' speaking skills with shorter period of time of research.

\section{REFERENCES}

Abdolrezapour, P. (2017). Improving learners' oral fluency through computer-mediated emotional intelligence activities. ReCALL, 29(1), 80-98. https://doi.org/https://doi.org/10.1017/S0958344016000069

Al-Tamimi, N. O. M., \& Attamimi, R. A. (2014). Effectiveness of cooperative learning in enhancing speaking skills and attitudes towards learning English. International Journal of Linguistics, 6(4), 27. https://doi.org/https://doi.org/10.5296/ijl.v6i4.6114

Beach, R., \& Myers, J. (2001). Inquiry-based English instruction: Engaging students in life and literature (Vol. 55). Teachers College Press.

Blessinger, P., \& Carfora, J. M. (2014). Inquiry-Based Learning for the Arts, Humanities and Social Sciences: A Conceptual and Practical Resource for Educators. Emerald Group Publishing.

Brown, H. D., \& Abeywickrama, P. (2004). Language assessment. Principles and Classroom Practices. White Plains, NY: Pearson Education. 
Brown, H., \& Lee, H. (2015). Teaching by Principles: An Interactive Approach to Language Pedagogy (Fourth Edi). London: White Palms: Pearson Education Inc.

Ermawati, Y., \& Pammu, A. (2017). The Implementation of Inquiry-Based Learning to Reading Comprehension of EFL Students. International Journal of Science and Research, 6(3), 1067-1071.

Harmer, J. (2001). How to Teach English. London: Longman.

Harmer, J. (2007). The Practice of English Language Learning (Fourth Edi). Harlow: Pearson Education, Inc.

Hunter, J. (2011). 'Small Talk': developing fluency, accuracy, and complexity in speaking. ELT Journal, 66(1), 30-41. https://doi.org/https://doi.org/10.1093/elt/ccr085

Ismail, A. I. (2014). Improving Speaking Ability of Eleventh Graders of SMAN 12 Surabaya through A Small Group Discussion Strategy. Universitas Negeri Malang.

Kampa, K., \& Vilina, C. (2016). How to Use Inquiry-Based Learning with Young Learners.

Kemmis dan McTaggart. (1988). Action research in retrospect and prospect, in Deakin University, The Action Research Reader. Victoria: Deakin University Press.

Kumaravadivelu, B. (2003). Beyond Methods: Macrostrategies for Language Teaching. Yale University Press.

Kumaravadivelu, B. (2006). Understanding Language Teaching: From Method to Postmethod. Routledge.

Laslett, R., \& Smith, C. (2002). Effective Classroom Management: A Teacher's Guide. Routledge.

Learning, A. (2004). Focus on inquiry: A teacher's guide to implementing inquiry-based learning. Retrieved September, 25, 2007.

Lee, William \& Owens, D. (2014). Multimedia-Based Instructional Design. In Igarss 2014 (Second). https://doi.org/10.1007/s13398-014-0173-7.2

Malmir, A., \& Shoorcheh, S. (2012). An Investigation of the Impact of Teaching Critical Thinking on the Iranian EFL Learners' Speaking Skill. Journal of Language Teaching and Research, 3(4), 608-617. https://doi.org/https://doi.org/10.4304/jltr.3.4.608-617

Masitoh, S. (2016). Peningkatan Hasil Belajar IPS Melalui Strategi Inquiry Discovery Learning di Kelas IV SDN Kecamatan Cikarang Utara Kabupaten Bekasi. Jurnal Pendidikan Dasar, 7(2), 341-360.

O'malley, J. M., \& Pierce, L. V. (1996). Authentic assessment for English Language Learners: Practical Approaches for Teachers. Addison-Wesley Publishing Company New York.

Oktariani, L. (2015). Improving Students' Reading Comprehension by Using Inquiry-Based Learning. Journal of Linguistics and Language Teaching, 2(1).

Puspitasari, D. (2014). Employing Inquiry-based Learning Strategy to Improve the Writing Ability of the Seventh Graders of SMP Laboratorium Universitas Negeri Malang. Unpublished Thesis. Universitas Negeri Malang, Malang.

Rachmawaty, N., \& Hermagustiana, I. (2015). Does Retelling Technique Improve Speaking Fluency? Teflin Journal, 21(1), 18.

Rossiter, M. J. (2009). Perceptions of L2 Fluency by Native and Non-Native Speakers of English. Canadian Modern Language Review, 65(3), 395-412. https://doi.org/https://doi: 10.3138/cmlr.65.3.395

Sholeh, M. B. (2008). Using Inquiry-Based Learning Strategy to Improve Descriptive Writing Ability of the Second Year Students of MTs. Al Ikhwan Klitik Demak. Universitas Negeri Malang.

Thayibah, N. (2013). Using Inquiry-Based Learning Strategy to Increase the Students' Score on Opinion Essays Writing of the Fourth Semester Students at English Department of IKIP Mataram. Universitas Negeri Malang.

Ur, P. (2012). A Course in English Language Teaching. Mexico: Cambridge University Press.

Walusi, W. (2016). Improving the Speaking Ability of the tenth Graders of SMPN 7 Binamu Jeneponto South Sulawesi Using Numbered Head Together Strategy. Unpublished Thesis. Universitas Negeri Malang, Malang. 